\title{
LAS SOCIEDADES MUSICALES EN EL MADRID DE ISABEL II (1833-1868)
}

\author{
Ma Aurelia Diez Huerga
}

\begin{abstract}
After the fall of the monarchist absolutism, the middle class, whom the economic liberalism gives an unprecedented strength, demands new entertainments, new places to make profitable social relationships and, definitely, new ways to show their influence and power. On the other hand, the shift of political rules allows people to express and gather, even if with some restrictions, and opens the door to the progressive democratization of society, with its cultural consequences. That ensemble of factors leads to the appearance of many different institutions but with a constant feature: the defence of the liberal ideas, the good fellowship and communication among individuals (which includes the recreational side), the cultural divulging and artistic expression. It is at this point that establishments with both musical and educational activity must be taken into account.

This essay intends to go through organizations such as Liceo Artístico y Literario, Instituto Español, La Unión, Museo Lírico, El Genio and many other artistic societies which proliferated during the 1830s and 1840s, centres with an intense social and musical activity in Madrid during Isabel II's era. Their influence in this area must be underlined, as devoted to promote performance, composition and, which is highly important, music instruction. The selected society of Madrid could be found there, gathered to learn music rudiments, singing and playing as well as to listen to the repertory in vogue at that time and to take part itself in its performance.
\end{abstract}

\section{Resumen}

Tras la caída del absolutismo monárquico, la burguesía, a quien el liberalismo económico dota de una pujanza sin precedentes, demanda nuevos entretenimientos, nuevos espacios para granjearse relaciones sociales convenientes y, en definitiva, nuevas formas para ostentar su influencia y poder. Por otra parte, el cambio de régimen político abre las puertas a las libertades de expresión y de reunión, aunque sea con matizaciones, y a la democratización progresiva de la sociedad, con sus derivaciones en el aspecto cultural. Tal confluencia de factores da pie a la aparición de instituciones de variada tipología pero con un denominador común: la defensa del ideario liberal, la convivencia y la comunicación de los individuos (lo que incluye el elemento recreativo), la propagación de la cultura y la expresión artística. Es aquí donde tienen cabida las sociedades con actividad musical, también denominadas instructo-recreativas, pues solían conjugar ambas facetas.

Este trabajo pretende hacer un recorrido por entidades tales como el Liceo Artístico y Literario, Instituto Español, La Unión, Museo Lírico, El Genio y muchas otras sociedades artísticas que proliferaron durante los años treinta y cuarenta del siglo XIX, centros de intensa actividad socio-musical en el Madrid isabelino. Se ha de subrayar su acción en este ámbito, dedicada a promover la interpretación, la creación y, en un plano importante, la enseñanza musical. En aquellos centros se dio cita la flor y nata de la sociedad madrileña para aprender los rudimentos de la música, el canto y la práctica instrumental así como para escuchar el repertorio que se estilaba por entonces y para participar ella misma en su interpretación.

La muerte de Fernando VII significa la oportunidad de que los liberales alcancen por tercera vez el poder en España - y, con ellos, el constitucionalismo-, por un lado, y el estallido de una cruenta guerra civil, por otro, que divide el país en dos bandos, los defensores del cambio de 
sistema y los partidarios del Antiguo Régimen. La nueva reina, obligada a apoyarse en los liberales con el fin de preservar el trono para su hija Isabel, es sensible a las presiones que, desde ese sector, exigen la deseada reforma política, reforma que ven seriamente amenazada por la sublevación carlista. Se inicia un proceso de transición que, de momento, no tiene como punto de mira el pleno liberalismo, sino que se trata de un pacto entre las partes interesadas, un acuerdo alcanzado a través de concesiones por parte de todos los bloques implicados. Ángel Bahamonde se refiere a una situación transitoria basada en «elementos políticos de la década absolutista que conjugan reformas administrativas con cierta apertura política, elementos del liberalismo moderado procedente del exilio que atempera sus posturas en una dirección posibilista, sectores del ejército, y la Corona, con sus personajes de camarilla y nobleza detrás» ${ }^{1}$. Se trata, pues, de una solución temporal, a modo de ensayo, por la cual se consigue dar gusto a todos, hasta cierto punto. La concreción de este nuevo sistema «híbrido» tiene lugar en el Estatuto Real, promulgado en abril de 1834, siguiendo modelos franceses y británicos.

Sin estar planteado como una constitución - ya que no apela a la soberanía nacional—, tampoco es, obviamente, una reproducción del estado institucional propio del Antiguo Régimen, pues establece una nueva fórmula de convocatoria a Cortes, así como la soberanía compartida por éstas y la Corona. Consiste en un articulado que intenta combinar la apertura política liberal con un fuerte protagonismo de la monarquía. Era el grado de representación que ésta se mostraba dispuesta a consentir y el grado de apertura con que los sectores reformistas estaban dispuestos a conformarse, una fórmula pactada que permita la acomodación transitoria de intereses opuestos, en el problemático contexto de una guerra civil. El régimen del Estatuto se sostuvo durante dos años, hasta que, en 1836, las demandas socio-políticas (que exigen mayor representatividad en las Cortes y, por consiguiente, mayor capacidad decisoria) y las propias circunstancias bélicas lo tornan insuficiente para abordar la situación del país. El giro hacia un estado plenamente liberal se hace ya necesario e imparable, y su instalación definitiva quedará establecida por la Constitución de 1837.

Mientras tanto, la reina gobernadora trata de contemporizar con todos, incluso con los más escépticos. Por una parte, el mantenimiento del sistema monárquico satisface a los apostólicos - acérrimos partidarios realistas-; por otra, la implantación de reformas políticas y administrativas persigue el afecto de los reformistas. Con tal intención se toman medidas claramente aperturistas, algunas ya decretadas poco antes del fallecimiento del monarca - recordemos la amnistía concedida a los liberales exiliados en la etapa precedente y la reapertura de las universidades, ambas promulgadas a finales de 1832-. Uno de los hitos del nuevo orden de cosas tiene que ver, sin duda alguna, con la libertad de expresión. Los decretos y reglamentos promulgados en 1834 sobre impresión, publicación y circulación de libros y de prensa periódica darán vía libre a una proliferación sin precedentes de periódicos y revistas. Gracias a ellos, la prensa adoptará un papel de primer orden en la difusión del ideario liberal y en la agitación política, no sólo

1. Bahamonde, Ángel - Martínez, Jesús A. Historia de España. Siglo XIX. Madrid, Cátedra, 1994, p. 185. 
durante las Regencias, sino también en la etapa isabelina - hay que mencionar la relevancia de publicaciones como El Español, La Abeja o El Eco del Comercio.

Ahora bien, Ángel Bahamonde acota las dimensiones de estos resultados al matizar que muchos de los títulos recientemente creados desaparecieron al poco tiempo. En una nación con elevados índices de analfabetismo, la producción de periódicos resultaba muy superior a la venta de los ejemplares, dada la preponderancia de la transmisión oral entre la población no instruida. Por otra parte, aunque es cierto que se facilitan los cauces para la libre expresión de las ideas, el marco legal que la regula es aún muy restrictivo. Los decretos insisten en lo que sus redactores denominaban «el justo medio», concebido como un estado a medio camino entre la ilimitada libertad de imprenta y las trabas e impedimentos sufridos durante el gobierno absolutista precedente. De hecho se establece una censura previa a la licencia de todas las obras que versen sobre religión, moral, política, historia, geología, viajes y recreo. A tal objeto se crea la Inspección General de Imprentas y Librerías del reino, órgano de control en manos de censores competentes en todas las materias sujetas a censura ${ }^{2}$.

Se trata, por tanto, de una libertad con matizaciones, que no sólo se aplicará al ámbito de la comunicación sino también al de la acción, pues, como dice Artola, «el triunfo del liberalismo significará, entre otras realizaciones, el reconocimiento de la libertad de expresión, llegándose muy pronto al establecimiento de una diferenciación entre la exposición doctrinal, que conocerá una gran tolerancia, y cualquier intento de realización práctica, que será perseguido siempre que constituya una amenaza para el régimen social y político» ${ }^{3}$. La restricción de la tolerancia política estará, de hecho, presente en las acciones gubernativas hasta el último tercio del siglo, afectando de manera especial al movimiento asociativo.

Junto al nuevo desarrollo editorial -innegable, aunque tamizado por la censura-, el reformismo político toma forma en la reapertura de las universidades y la fundación de otras instituciones que actuarán como centros primordiales en la difusión cultural y el debate político. Poco después, estas iniciativas darán pie a otras de talante artístico y recreativo, donde, por primera vez en la historia de nuestro país, la música asumirá el protagonismo - especialmente en las sociedades musicales- Asistimos, pues, a la aparición de las primeras manifestaciones de sociabilidad formal o institucionalizada, ahora abiertamente reconocidas, en un marco propicio ya para el asociacionismo, de imparable proyección a escala nacional durante el resto de la centuria y parte de la siguiente. El movimiento asociativo nace en esta década con el fin de satisfacer las necesidades de comunicación social en los ámbitos de la cultura, la expresión artística, el ocio y, más tarde, como medio de reivindicación y defensa político-económicas, convirtiéndose en un fenómeno sociológico asombrosamente prolífico. No en vano Bartolomé Bennassar ha comentado en relación al XIX español que, «así como el siglo XVIII fue el de las academias y Sociedades Económicas, la época que nos ocupa es la de los ateneos y de los casinos» ${ }^{4}$.

2. Ibidem nota anterior.

3. Artola, Miguel. La burguesía revolucionaria (1808-1874). Madrid, Alianza, 1983, p. 332.

4. Bennassar, Bartolomé. Historia de los españoles 2. Siglos XVIII-XIX. Barcelona, Crítica, 1989, p. 167. 
Centrándonos en el papel ejercido por las sociedades musicales decimonónicas, hemos de citar los trabajos de $\mathrm{M}^{\mathrm{a}}$ Encina Cortizo y Ramón Sobrino, entre los pocos investigadores que han iniciado una aproximación al tema desde el terreno de la musicología. Ambos subrayan la importancia de dos factores cuya concomitancia fue, sin duda alguna, el detonante para el desarrollo del asociacionismo musical y, parcialmente, para todo el fenómeno en términos generales. En primer lugar, la renovación política emprendida por la regente $\mathrm{M}^{\mathrm{a}}$ Cristina implicó un giro hacia el liberalismo y, con él, la repatriación de los exiliados durante los años de régimen absolutista. El regreso de los emigrados fue, sin duda, un evento crucial para el devenir histórico español, ya que supuso la penetración del movimiento romántico en nuestro país, junto a modelos culturales y sociales europeos, predominantemente franceses, ingleses y alemanes ${ }^{5}$.

El asociacionismo, prohibido en el período absolutista por miedo a insurrecciones políticas - a excepción de las Sociedades Económicas-, se convierte ahora en uno de los espacios para la difusión del ideario liberal. «A partir del momento en que los liberales ocuparon el poder por tercera vez en España en 1834, se constata el ansia por la teorización política y un fuerte afán doctrinal de exposición y justificación de los principios que sustentaban su ideología. Ya desde 1833 aparece una generación de teóricos moderados [...] que, como Donoso Cortés, Pacheco, Durán, Gallardo, Alcalá Galiano, Borrego, presentan en artículos de fondo, libros y conferencias en el Ateneo de Madrid una edificación jurídica del nuevo orden» ${ }^{6}$. Curiosamente, espacios hasta el momento vedados por causas políticas son ahora utilizados por razones de la misma naturale$\mathrm{za}$, aunque de signo contrario. Inmediatamente, a partir de ese primer brote - hablamos del mencionado Ateneo-, surgirán iniciativas similares estructuralmente, pero con otras finalidades, como la artística o la recreativa - sociedades musicales, liceos, círculos- y muchas otras que jalonarán el paisaje social en años venideros.

Retomando las aportaciones de $\mathrm{M}^{\mathrm{a}}$ Encina Cortizo y Ramón Sobrino en el terreno del asociacionismo musical, ambos autores localizan el segundo factor desencadenante de dicho fenómeno en las medidas desamortizadoras emprendidas por Juan Álvarez de Mendizábal, jefe del Gobierno y ministro de Hacienda entre finales de 1835 y mediados de 1836. Estas iniciativas se enmarcan en el plan general de reformas hacendísticas ideado por dicho mandatario para aliviar la crisis económica que afectaba a un país inmerso en plena guerra civil. El objetivo era reducir los gastos del Estado y elevar sus ingresos sin tener que recurrir al aumento de los impuestos o a los préstamos en el extranjero. Para ello, una de las jugadas clave fue la confiscación de las propiedades eclesiásticas — jurídicamente clasificadas en bienes «de mano muerta»— y su venta en pública subasta. Se procedió al cierre de conventos y a la supresión de comunidades religiosas que no prestaban servicios sociales, tales como la enseñanza a pobres, cuidado de enfermos $u$ obras misionales - a excepción de algunas órdenes-, servicios que la ideología liberal consideraba útiles, equiparables a la beneficencia estatal. Los bienes de las congregaciones suprimidas

5. Cortizo, $M^{a}$ Encina - Sobrino, Ramón. «Asociacionismo musical en España». Sociedades musicales en España. Siglos XIX y XX. Madrid, Fundación Autor, 2001, pp. 11-16.

6. Rodríguez Alonso, Manuel. «El Estado liberal español (1834-1874)». Historia contemporánea de España (1808-1939), Javier Paredes (coord.). Barcelona, Ariel, 1996, p. 196. 
fueron declarados «nacionales» y posteriormente completados con la expropiación de los del clero secular.

A. Díez Torre sostiene que el programa desamortizador de Mendizábal ocultaba una finalidad política vinculada al desmantelamiento del poder económico de la Iglesia, hasta entonces uno de los pilares esenciales del Antiguo Régimen. Por otra parte, su balance fue negativo para las arcas del Estado, ya que aumentaron los gastos públicos en concepto de servicios de beneficencia - al hacerse cargo de un elevado número de necesitados que los religiosos asistían hasta entonces - y la mayor parte de las propiedades desvinculadas fueron vendidas a precios irrisorios, con lo cual poco fue recaudado por la Hacienda pública ${ }^{7}$.

Aparte de su ineficacia en el terreno económico, la desamortización fue realmente nefasta para la cultura española y, de un modo especial, para la música. La pérdida de las propiedades implicó la privación de los medios necesarios para el sostenimiento de las capillas eclesiásticas, con una doble consecuencia: laboral y pedagógica, por simplificarlo de algún modo. El cierre de capillas catedralicias y eclesiásticas en todo el territorio nacional significó el despido de cientos de músicos profesionales que se ven ahora literalmente «en la calle» y, privados de su sustento, han de buscar otros modos de subsistencia. La situación debió de ser realmente crítica durante los años treinta y cuarenta, a juzgar por la reseña periodística aparecida en La Iberia Musical de 1842, testimonio de la indigencia padecida por muchos artistas:

«Hemos visto con el mayor dolor pedir limosna en la puerta de la iglesia de San Luis, al profesor D. Modesto Berbén, organista que fue de la Real Capilla de S. M. Esta situación tan lamentable a que hemos visto reducido a un buen compañero de profesión ha inducido a la redacción (y ya está trabajando con actividad para el efecto) a formar una sociedad de socorros mutuos para aliviar la suerte adversa de los profesores que se encuentren en este caso. Los trabajos que se hagan para llevar adelante esta empresa La Iberia los manifestará, y no dudamos que los profesores de Madrid se prestarán gustosos a tan laudable objeto» ${ }^{8}$.

Pero, si la noticia anterior resulta impactante, la «llamada de socorro» redactada por J. Espín y Guillén un año después en la misma publicación es realmente desgarradora:

«Hoy tenemos que llenar un deber tan triste como sagrado para nosotros, hoy tenemos que dejar á un lado el lenguaje de vida y de ilusión, para entrar á manifestar las calamidades y miserias de que se hallan rodeados beneméritos artistas. Doloroso nos es el que en un pais donde hay tantos elementos de vida para las artes, donde contamos con una juventud ardiente y decidida, se vean las primeras abandonadas, y los últimos desatendidos.

Infinita correspondencia hemos recibido en estos últimos dias, de maestros de capilla y organistas de varias catedrales y colegiatas, en que nos suplican con lágrimas en los ojos miremos por su situación precaria y miserable, por una existencia que sostienen milagrosamente y porque se ven próximos á bajar al sepulcro, sin que el gobierno les eche una mirada de compasión. Oh! Este cua-

7. Díez Torre, Alejandro R. «Las regencias de María Cristina (1833-1840) y de Espartero (1840-1843)». Historia contemporánea de España (1808-1939)..., pp. 220 y ss.

8. «Crónica nacional». La Iberia Musical, año I, nº 3. Madrid (16-I-1842), p. 12. 
dro es horrible y despedaza el alma; es horrible, sí, porque al ver que unos hombres que han conquistado sus plazas á fuerza de talento y de saber, á unos hombres que se han presentado á la palestra en públicas oposiciones, ganando sus plazas con gotas de sangre; á unos hombres que deben su patrimonio tan solo á su talento y nada á la intriga, es horrible, infame, inhumano, el que se les quite de la boca un miserable pedazo de pan á que se veian hoy reducidos, dejando morir en la mas cruel agonia á una clase respetable, honor de la patria que le dio el ser, y del arte que con tanto honor cultivan [...] Situación tremenda, angustiosa es la nuestra; vemos perecer el arte y á las columnas mas fuertes de él; vemos que dentro de muy pocos años va á desaparecer la escuela sacra de música que tanto renombre nos ha alcanzado en Europa, y que el único fruto que podremos dar en adelante será una ópera llena de plagios, ó una tanda de rigodones ó valses para que el vulgo ria y los artistas sean el escarnio del estrangero (sic) [...] No olvide el gobierno la suerte de tantos desgraciados artistas que se hallan hoy dia implorando la caridad pública, haga que se les atienda en el pago respectivo de sus asignaciones, y de esta manera podrá alcanzar el renombre de justo y protector de las artes» ${ }^{9}$

Es en este punto donde harán su entrada diversas sociedades musicales como estructuras que auxilien a los nuevos desempleados en su precariedad. Con tal finalidad se constituirán las denominadas Sociedades de Socorros Mutuos durante el resto de la centuria, iniciativa que será igualmente adoptada en otros colectivos. Pero, antes de que ese tipo de corporativismo aparezca, diversas instituciones contribuirán al sostenimiento de estos músicos, al contratarlos para participar en conciertos y lecciones destinados a sus socios - bien como solistas o en orquestas-e, incluso, organizando actividades para recaudar fondos en su beneficio.

Si en algo se vieron favorecidas las nuevas corporaciones fue en la disponibilidad de espacios libres para la instalación de sus sedes, muchas de ellas ubicadas en conventos, monasterios o iglesias desalojados por sus antiguos ocupantes, ahora remodelados para las entidades civiles.

Aparte de las sociedades, los anteriores empleados de la Iglesia buscan trabajo en cafés o tablaos (sin olvidar los teatros y las clases particulares). De hecho, constata E. Casares, el café - en sus variantes de café cantante, café lírico y café teatro- se convierte en uno de los espacios musicales paralelos a los salones, «constituye un núcleo relevante en la estructura musical decimonónica, es el más numeroso y es el hogar musical del aficionado socialmente más bajo» ${ }^{10}$. $\mathrm{Su}$ actividad, habitualmente centrada en un piano o un pequeño grupo de cámara, persiste hasta la guerra civil de 1936, cuando ya no puede competir con los nuevos medios de difusión musical, como la radio o el gramófono, generándose una situación de inestabilidad para los músicos.

Con la desamortización, la enseñanza musical española sufre un duro golpe (y, en consecuencia, la cultura), ya que el cierre de las capillas se traduce en la desaparición de los principales centros de docencia musical del país durante siglos, con el subsiguiente perjuicio para la formación de los profesionales de este arte. Sin estructuras adecuadas a tal fin, el Estado español

9. ESPín y GUILLÉN, Joaquín. «Estado deplorable de nuestros comprofesores». La Iberia Musical y Literaria, año II, $\mathrm{n}^{\circ}$ 1. Madrid (1-I-1843), p. 4.

10. CaSAREs Rodicio, Emilio. «La música del siglo XIX español. Conceptos fundamentales». La música española en el siglo XIX. Universidad de Oviedo, 1995, p. 44. 
asumirá con lentitud y muchas deficiencias esta responsabilidad a lo largo del XIX. Parte de ella será adoptada por sociedades artísticas y musicales, al crear cátedras de música para sus socios.

Por último, hay que recordar las implicaciones que las medidas económicas tuvieron en el ámbito creativo. Disminuirá el volumen de las composiciones religiosas, al ser desplazadas por obras de otro tipo y para otras circunstancias, las que el público demanda y aseguran la subsistencia de los músicos, estrechamente vinculadas al repertorio consumido en salones, sociedades y cafés. Música comúnmente definida como mediocre y sin pretensiones en muchos casos, los compositores sólo podrán evitarla si son capaces de triunfar o, al menos, de abrirse un hueco en el mundo del teatro, donde se hace «la gran música» ${ }^{11}$.

El primer paso en el movimiento asociativo tras el período absolutista fue protagonizado en 1835 por el Ateneo Científico, Literario y Artístico de Madrid, surgido en el seno de la Sociedad Económica Matritense. Según V. García Martí, el Ateneo Español fue un antecedente, pero con un sentido distinto. Sin ser una reapertura del malhadado Ateneo Español de la época del Trienio, sí pretende, al menos, retomar su espíritu y su línea de funcionamiento ${ }^{12}$.

Nos hallamos, por tanto, ante una institución cuyo objeto es el debate político y social unido a la comunicación científico-literaria, bajo la triple identidad de Academia, Instituto de Enseñanza y Círculo Literario, a lo que habrá que añadir una cuarta faceta como Escuela de Estudios Superiores, creada en los últimos años del siglo. Como ente cultural y centro de difusión y debate, acusará el paso de las corrientes de pensamiento político y filosófico que surcan el XIX -recordemos el krausismo, el positivismo o el neokantismo-y, cómo no, aquellas de corte literario, tales como el realismo y el naturalismo.

El carácter de círculo literario incluye asimismo la expresión artística, apareciendo ambas facetas ya en los orígenes de la institución. Aunque forman parte de sus atribuciones, la brillante actividad desplegada por el Ateneo en calidad de Academia e Instituto oscureció de forma evidente su quehacer artístico. Este segundo plano al que se vio relegada la actividad artística se hace patente en la prensa periódica a lo largo del siglo. Revisando las publicaciones de carácter específico podemos ver que, al menos durante la primera mitad del XIX, los anuncios y reseñas periodísticas referentes al Ateneo de Madrid brillan por su ausencia, lo que no sucede con otras entidades — como el Liceo o el Instituto-, surgidas poco tiempo después. La vida del Liceo, con sus exposiciones, sus cátedras públicas, conciertos, representaciones dramáticas y veladas artísticas, parece obnubilar la del Ateneo (si es que se daba, como reza en sus actas) en buena parte del siglo, a juzgar por la prensa. No obstante, el esplendor del Liceo será un acicate para él y a su modelo tratará de aproximarse con el paso de los años. Prueba de la ascendente proyección de la actividad artística en el Ateneo es la especialización que alcanzará en las últimas décadas. En 1884 el Círculo Artístico y Literario se dividirá en dos secciones, Literatura y Bellas Artes, desgajándose una nueva sección de Música diez años después y la de Artes Plásticas en 1900. El apogeo de estas secciones se hará evidente a principios del $\mathrm{XX}$, adquiriendo notoria preponde-

11. Ibidem nota anterior.

12. García Martí, Victoriano. El Ateneo de Madrid (1835-1935). Madrid, Dossat, 1948, pp. 39-40. 
rancia sobre la Academia y el Instituto. F. Villacorta ha señalado en su estudio sobre esta sociedad que la creciente potenciación de las inquietudes artísticas y literarias dentro del conjunto de su actividad es, precisamente, uno de los rasgos más sobresalientes en la evolución del Ateneo, especialmente en las postrimerías del XIX. Es, a su juicio, un rasgo significativo.

«Representa el desplazamiento parcial de su pasada gravedad doctrinal en la política y en la cultura superior a favor de propuestas culturales más fácilmente asumibles por grupos sociales alejados del mundo de la política profesional y del académico. No quiere esto decir que esas dos tradiciones hayan quedado rotas en el Ateneo, sino que han modificado sus vínculos con la institución. Cada vez con mayor nitidez el Ateneo se convierte en una plataforma ocasional de promoción política y profesional [...] pero la diferencia es que ahora lo hace vacío de contenido propio. Entonces en el Ateneo se hacía la política y la cultura superior de la España contemporánea; ahora sólo se difunde» ${ }^{13}$.

Sin embargo, esto sucederá después de varias décadas de funcionamiento, durante las cuales otras sociedades toman las riendas como paradigmas del asociacionismo artístico-musical. Hablamos del Liceo, en el que nos detendremos más adelante.

El protagonismo en las secciones artísticas durante sus años de esplendor estuvo acaparado por las veladas literario-musicales - conciertos, lectura o representación de obras, estudios críticos sobre algún autor homenajeado - en detrimento de los debates, conferencias y discusión de memorias, cotidianas en el resto de las disciplinas y centro de la vida intelectual de la asociación. Por ellas pasa lo más granado de las letras y las artes españolas: Campoamor, Núñez de Arce, Echegaray, Fernández Shaw, Bretón, Chueca, Pedrell, entre otros, junto a primeras figuras del canto y la interpretación, niños prodigio y alumnos premiados por el conservatorio. Todos ellos «pasan por el Ateneo para recibir el bautismo de una institución de indudable prestigio», difundiendo una «producción fácil y placentera, destinada a la cómoda y mentalmente perezosa burguesía», quien ostenta «un gusto malo, incierto y fácil de contentar» ${ }^{14}$.

El Ateneo del XIX, si bien pionero del fenómeno asociativo emergente en los años treinta, en términos generales, no fue el patrón que las sociedades artístico-musicales adoptaron como referencia, globalmente hablando. Aunque su estructura sí fue tomada como modelo organizativo - estatutos, secciones, cátedras-, quizá porque la mayor parte de sus disciplinas quedaban fuera de las competencias de este tipo de asociaciones - como las de carácter político y científico, verdadero centro de la vida «ateneista»- y porque su actividad artística había permanecido en segundo plano durante décadas, las asociaciones musicales posteriores prefirieron seguir la pauta de otra institución más en consonancia con sus pretensiones: el Liceo, uno de los centros neurálgicos de la intensa vida socio-musical que la burguesía madrileña protagoniza durante los años treinta y cuarenta. No obstante, el Ateneo de Madrid, con sus épocas de crisis y de brillantez, tiene el mérito de haber logrado mantenerse en activo hasta la actualidad, cosa que no ha

13. Villacorta Baños, Francisco. El Ateneo Científico, Literario y Artístico de Madrid (1885-1912). Madrid, CSIC, 1985, p. 214.

14. Ibidem nota anterior, p. 212. 
sucedido con la mayoría de las otras entidades, en clara decadencia durante la segunda mitad del siglo XIX.

El Liceo Artístico y Literario nace, como su nombre indica, para constituirse en «sociedad exclusivamente dedicada a procurar el fomento y prosperidad de la literatura y bellas artes» ${ }^{15}$, sin interés por las actividades científicas o políticas. A diferencia del Ateneo, que aflora en el seno de otra sociedad - la Matritense-, el Liceo fue fruto de una iniciativa particular. La idea fue concebida por José Fernández de la Vega, asiduo concurrente a la tertulia del Parnasillo (en el café del Príncipe, la más notoria entre las frecuentadas por los intelectuales durante los últimos años del reinado fernandino) y promotor de una velada literaria en su propia residencia. La intención de dar un carácter periódico a aquellas reuniones de literatos y artistas se llevó a la práctica en 1837, dos años más tarde que la del Ateneo.

Siendo su primera sede la casa del fundador, la ascendente concurrencia obligó a la nueva institución a mudarse sucesivamente durante los primeros meses:

«la primera noche de reunión, que, según mi cálculo, pudo ser en los últimos días del mes de marzo de 1837, sólo la formábamos hasta una docena de personas [...]. En aquella primera reunión se leyeron por éste algunas de sus originales y bellísimas poesías, y por los pintores se hicieron algunos dibujos, despidiéndose cordialmente para el jueves próximo. En éste se duplicó la concurrencia, triplicase el tercero y, no cabiendo en aquella modesta habitación, el intrépido Fernández de la Vega se trasladó al cuarto principal de la misma casa, donde pudo funcionar la tertulia con algún más desahogo unas cuantas semanas más» ${ }^{16}$,

hasta que, tras nuevos traslados, a principios de 1838 se establece en la que será su residencia definitiva, con la presencia de la reina en la sesión inaugural (quien, por cierto, tomará parta en veladas posteriores, interpretando ella misma piezas instrumentales).

La estructura es similar a la del Ateneo en lo que respecta a la división en secciones, verificándose las de literatura, pintura, escultura, arquitectura, música y la originalmente denominada «adictos», cuyos socios sólo contribuían al sostenimiento de la entidad por medio de una cuota. Las aportaciones de los asociados variaban en función de la sección a la que perteneciesen, tal y como estipulan los estatutos:

«Artículo $3^{\circ}$. Las cinco secciones y los adictos internos contribuirán al sostenimiento del Liceo en esta forma: Literatura. Cada uno de sus individuos dará al Liceo mensualmente una composición en verso o prosa. Pintura. La sección entregará cada mes una obra litográfica en estado de estampación. Escultura. Del mismo modo, y cada dos meses dará ésta un diseño litográfico. Arquitectura. Alternando con este periódico, entregará la sección un diseño litográfico de una obra o proyecto en igual forma. Música. Esta sección entregará mensualmente una composición original» ${ }^{17}$.

15. Semanario Pintoresco Español, n 95 , Madrid (21-I-1838).

16. Mesonero Romanos, Ramón. Memorias de un setentón. Madrid, Oficinas de la Ilustración Española y Americana, 1881. Edición consultada por la autora: Madrid, Tebas, 1975, p. 368.

17. «Constituciones del Liceo Artístico y Literario Español», en Suplemento de El Liceo Artístico y Literario. Madrid, 1838 , cap. $2^{\circ}$, pp. 49 y ss. 
A semejanza del Ateneo, el Liceo contó con una biblioteca, con la particularidad de que ésta se surtía básicamente de las obras escritas por los socios. A ello hay que añadir el museo, creado con idéntica finalidad para las aportaciones de los otros departamentos, signo de su inherente vocación cultural y su afán por legar una herencia a la posteridad:

«Art. $6^{\circ}$. Formará el Liceo una biblioteca de las obras publicadas o que publicasen sus individuos, un museo de pintura y escultura con una de cada profesor, y archivará otra de cada individuo de las secciones de competencia semanal concurrida de todas las secciones.

Art. $7^{\circ}$. Establecerá el Liceo un salón público para depositar en él las obras que los profesores quieran enajenar» ${ }^{18}$.

Otra similitud con aquel centro fue la publicación de su propia revista, El Liceo Artístico y Literario, proyecto que sucumbió el mismo año de su creación, 1838.

La agitada vida del Liceo se nutría de lecturas desde la tribuna, discusiones privadas en las secciones, cátedras públicas regentadas por los socios (recordemos las de Música, Solfeo y Canto), exposiciones de pintura y escultura, conciertos y veladas literario-musicales (en las que se recitaban poemas y se interpretaban obras). Pero el «momento estrella» de su actividad llegaba con la tarde de los jueves, cuando la confluencia abarrotaba las dependencias del palacio de Balmaseda con ocasión de la muy esperada y ya célebre «sesión de competencia»:

«Allí, en aquellos espléndidos salones, decorados y alumbrados con profusión y henchidos de toda la más brillante sociedad de la corte, y en muchas ocasiones con asistencia de la Reina y la Familia real, el Gobierno y el Cuerpo Diplomático extranjero, se celebraban aquellos inolvidables jueves del Liceo, aquellas sesiones de competencia artística y literaria, aquellos Juegos Florales, aquellos conciertos y representaciones dramáticas y líricas, en que brillaban alternativamente los antiguos campeones de la literatura y del arte con los nuevos ingenios que surgieron como por encanto en aquella época fecunda» ${ }^{19}$.

Aquellas sesiones, en las que se daba cita lo más selecto de la sociedad, brindaban a los socios la oportunidad de demostrar sus adelantos en las diversas disciplinas contempladas por las secciones - recitado de poemas, interpretaciones musicales...- convirtiéndose en una suerte de «emporio» de las artes. Celsa Alonso apunta al respecto que «la música empezó a tener un lugar importante entre las actividades del Liceo, pero sin olvidar el espíritu de hermanamiento entre las artes, un claro síntoma de modernidad ${ }^{20}$. Muestra de ello es la siguiente reseña periodística de 1839:

«LICEO.- La sesión del último jueves ha estado brillante. Se verificó en el gran salón de Villa-hermosa, y apenas bastaba á contener la numerosa y escogida sociedad que lo llenaba. Todas

18. Ibidem nota anterior.

19. Mesonero Romanos, R. Memorias..., p. 370.

20. Alonso, Celsa. «Un espacio de sociabilidad musical en la España romántica: las sociedades instructo-recreativas». Sociedades musicales en España. Siglos XIX-XX. Madrid, Fundación Autor, 2001, p. 26. 
las secciones dieron como siempre pruebas de su inteligencia y actividad. Llamó la atención en la de pintura la prontitud y perfección con que ejecutó el señor Cabana el retrato de nuestro amigo y colaborador D. Patricio de la Escosura. Los literatos se mostraron un tanto perezosos; no así los músicos, que arrancaron prolongados aplausos. El señor Siguer entusiasmó con unas variaciones de violin; la señora Lema de Vega cantó inimitablemente el rondó de la Lucía, y el señor Escobedo manifestó sus buenas disposiciones en una cavatina del Pirata. Otras piezas hubo también que ahora no recordamos» ${ }^{21}$.

Al poco de ponerse en marcha, la actividad del Liceo madrileño se vio enriquecida con dos nuevas aportaciones musicales, pues, como constata el marqués de Mendigorría,

«poco después se inauguraron allí grandes bailes de máscaras, que pretendieron rivalizar, por lo aristocráticos, sin conseguirlo, con los de Santa Catalina; y en el mismo invierno construyeron en el gran salón un teatro, que formó época por las notabilidades artísticas de todo género que pisaron sus tablas» ${ }^{22}$.

La construcción del teatro corre paralela a la creación de una nueva sección, orientada al arte dramático, en 1839:

«NUEVA SECCIÓN DEL LICEO.= En la noche del lunes ultimo quedó constituida la sección dramática, eligiendo por su presidente al Sr. D. Ventura de la Vega. Entre los sugetos (sic) que la componen, se hallan los mejores aficionados de Madrid; los cuales se preparan ya para las funciones que deben ejecutar en el teatro que se va á construir al efecto en el gran Salon del Palacio de Villahermosa» ${ }^{23}$.

Los socios de esta sección contaban habitualmente con la colaboración de actores profesionales para las representaciones teatrales, ya que «las grandes actrices del teatro del Príncipe, y entre ellas principalmente Bárbara Lamadrid, auxiliaban en estas empresas artísticas a los aficionados, cuyos nombres siento no recordar» ${ }^{24}$. En realidad, la participación de diletantes y profesionales estaba a la orden del día en todas las secciones, como se puede inferir a partir de las memorias de nuestro entrañable setentón, quien, ostentando una memoria mucho más lúcida que la del marqués, no repara en nombres:

«Allí, en los otros departamentos, los célebres pintores de cámara López y Madrazo y sus hijos, Esquibel, Guiterrez de la Vega, Villaamil, Elbo, Jimeno, Tejeo, cruzaban sus pinceles con aficionados ilustres, como los duques de Gor y Rivas y las señoritas Weis y Menchaca. Allí, en su elegantísimo teatro, ostentaban su talento escénico, a par de Matilde Díez, Isabel Luna, la Tablares, la Chafino y otras artistas de profesión; Joaquina Romea, la señora de Ojeda, Manolita Lema,

21. «Telégrafo literario», El Entreacto, año I, n 9. Madrid (28-IV-1839), p. 36.

22. Fernández de Córdova, Fernando. Mis memorias íntimas. Madrid, 1889. Edición consultada: Madrid, Atlas, 1996, p. 344

23. «Telégrafo literario», El Entreacto, año I, n 2. Madrid (4-IV-1839), p. 8.

24. Fernández de Córdova, F. Mis memorias..., p. 344. 
Natividad Rojas y Antonia Montenegro, con Ventura de la Vega, Ruiz de Arana, Alvarez, Piquer, Escobar (don Telesforo y don Ignacio), Marraci, Segovia y Sartorius. Allí, en fin, ayudados por una brillante orquesta de profesores y aficionados, se hicieron oír, en magníficos conciertos y óperas, el incomparable Rubini, la Paulina García (Mme. Viardot), llamados expresamente por la sociedad, y los admirables concertistas Listz, Talberg y otras celebridades europeas» ${ }^{25}$.

Por la sección de música pasaron los nombres de Mariano Rodríguez Ledesma, Pedro Albéniz, Ángel Inzenga, Juan Guerbós, José Sobejano, Juan Ficher, Manuel Ducassi, Joaquín Espín, Baltasar Saldoni, Sebastián de Iradier, entre muchos otros.

Durante los años cuarenta asistimos a varios momentos de crisis en la actividad de la institución. En 1842 la sección de música interrumpe sus sesiones por problemas con el profesorado, recuperándose al año siguiente. Posteriormente, en 1848, dificultades económicas le obligan a cerrar sus instalaciones, las cuales, por fortuna, se reabren a los pocos meses, a la par que una renovación en la junta directiva de la asociación y en la organización de la misma. A decir verdad, los últimos años de la década serán el preludio de un declive acusado por la generalidad de las sociedades musicales, como veremos.

La iniciativa del Liceo capitalino fue secundada en numerosas ciudades españolas. Centros de este tipo florecen en Valencia, Sevilla, Barcelona, Granada, Valladolid, Santander, Cádiz... en las décadas de los treinta y cuarenta, incluso en localidades menores — véase Ciudad Rodrigo, Écija, Úbeda o Avilés, por dar algunos nombres-. C. Alonso ha subrayado la trascendencia de la labor desempeñada por los liceos de provincias, sobre todo en lo que se refiere a la difusión de repertorio operístico, de difícil acceso fuera de los centros neurálgicos del país - Madrid y Barcelona-, dada la crisis económica que padecen los teatros a la sazón y, en términos generales, el penoso estado de un país en guerra ${ }^{26}$.

El Liceo logró despertar el interés creativo de los burgueses madrileños, que al poco se decidieron a fundar sociedades similares o, al menos, parcialmente emuladoras de su actividad, añadiendo algunas de ellas las facetas lúdica y pedagógica a la artística. De esta simbiosis proceden las denominadas sociedades instructo-recreativas, por condensar de alguna forma la terminología.

El asociacionismo español recibe un notorio impulso en 1839, con la promulgación de la Real Orden de 28 de febrero, por la cual el Gobierno amplía las concesiones en el ámbito del corporativismo. Ello no significaba plena libertad, pues, como hemos visto, ésta fue coartada de un modo u otro durante todo el siglo, especialmente en lo tocante a sus implicaciones políticas. Sin embargo, conllevó un reconocimiento de los derechos de reunión y asociación sin precedentes en nuestro país, derivando en un asombroso florecimiento de instituciones de todo tipo.

Un breve recorrido por diversas asociaciones que contribuyeron a enriquecer la vida socio-musical en el Madrid de los cuarenta nos obliga a detenernos en el Instituto Español. Fun-

25. Mesonero Romanos, R. Memorias..., p. 370.

26. Alonso, C. «Un espacio de sociabilidad musical en la España romántica...», p. 24. 
dado por el marqués de Sauli en 1839 para encauzar, a través de una forma organizada estatutariamente (aprovechando la nueva coyuntura legislativa, favorable al asociacionismo a raíz del Real Decreto), las actividades que él y un grupo de amigos venían desempeñando por entonces de un modo más informal. $\mathrm{M}^{\mathrm{a}}$ Encina Cortizo ha distinguido tres períodos en la trayectoria de la institución: etapa inicial (1839-1841), años de esplendor (1842-1846) y decadencia (1847-1852), caracterizándolas por «la lucha por la estabilidad y el comienzo de todas las actividades en los orígenes, el inicio de la escuela lírico-práctica y la inauguración de un nuevo teatro de «primer orden» en los años de esplendor, y la lánguida existencia, en cierta manera heroica, ya en la decadencia ${ }^{27}$. La nueva asociación comienza su andadura en clara emulación de la estela dejada por el Liceo, como puede apreciarse en la reseña periodística que a continuación damos, la cual resume una sesión de competencia en el estilo propio de aquella sociedad:

«La sesion celebrada la noche del 16 fue la mas concurrida de todas las que hemos presenciado. Una animación tan extraordinaria y siempre en progresión ascendente prueba bien la necesidad de un local mas ancho y capaz: muy en breve tendrán los señores socios de este establecimiento el placer de verificar su traslacion, pues gracias á la actividad de su digno presidente se han tomado todas las disposiciones conducentes al asunto y se está preparando el nuevo salon que después del del Liceo será el mas vasto de que tenemos noticia.

Las piezas de música que tuvieron lugar la noche del 16, fueron las siguientes.

$1^{\circ}$. Valses de Straus por la orquesta.

$2^{\circ}$. Duo de Capuletti é Montecchi por la señorita Ibarrondo y el señor Amerigo.

$3^{\circ}$. Variaciones de clarinete con acompañamiento de orquesta.

$4^{\circ}$. Duo de la Straniera por la señorita Garcia y señor Castellanos.

$5^{\circ}$. Otra colección de Valses de Straus, por la orquesta.

$6^{\circ}$. Una cavatina cantada por la señorita Ibarrondo.

$7^{\circ}$. Duo del Posto Abbandonato por la señorita Garcia.

$8^{\circ}$. Cavatina de Kenilworth por la señorita Garcia y el señor Salas.

En los intermedios leyeron los señores Elipe, Alegre, Campoamor, Azquerino, Rubí y Castellanos, y tanto la seccion de literatura como la de música llenaron deliciosamente los deseos de la concurrencia.

La seccion de pintura estuvo tambien animada. Pintaron los señores Bravo, Menendez, Maffei, Barrios y Rotondo. El escultor don Nicolas Fernandez modeló un precioso medallón retrato de una señorita de la reunion.

Tenemos noticia de que la mesa de artes se halla ya constituida, siendo sus individuos los señores artistas de cámara y director de las Academias de esta córte; entre ellos don Francisco Elias, primer escucltor de cámara» ${ }^{28}$.

Del mismo modo se organiza en cátedras y secciones, con la diferencia de que éstas son: Ciencias y Literatura, Artes, Música, Comercio y Damas, reservando la última para los socios

27. Cortizo, $\mathrm{M}^{\mathrm{a}} \mathrm{E}$. «El asociacionismo en los orígenes de la zarzuela moderna», Sociedades Musicales en Espa$\tilde{n} a \ldots$, p. 47

28. «Instituto Español». El Entreacto, año I, n 69. Madrid (24-XI-1839), p. 273. 
femeninos. Se trata de un centro cultural de carácter ecléctico, al cultivar las facetas científica, artística y literaria, con mayor amplitud de miras en ese sentido que el Liceo.

Las sesiones de competencia, junto a las propias de cada departamento - como las veladas filarmónicas, en el caso de la sección de música- marcan una línea común en el funcionamiento de ambos centros, a lo que hay que añadir los bailes organizados, motivo de encuentro para la sociedad más encopetada, como complemento de su faceta social. Sin embargo, al poco de su fundación, en el Instituto se idean varios proyectos sociales, con fines económico, por un lado, y docente, por otro, que vendrán a confirmar una doble vocación benéfica y pedagógica no compartida por la otra entidad:

«El reglamento de esta corporación se dará á luz muy pronto. Las bases de que consta nos parecen las mas oportunas y acertadas. Entre sus disposiciones se trata de formar un monte pio y la correspondiente sociedad de socorros mutuos en beneficio de los literatos y artistas del establecimiento que contribuyan con la módica cantidad que el reglamento particular designe al efecto. Socorrer la desgracia de los literatos y artistas, según lo permita el estado de los fondos del establecimiento, es tambien otro de los pensamientos que mas adelante se piensa llevar á cabo. Esto unido al establecimiento de las escuelas de niñas y adultos, nos hace presagiar que el Instituto español será con el tiempo una de las corporaciones literarias y artísticas mas útiles de la corte. Su digno presidente es por dicha un sugeto activo y emprendedor, y sabrá poner en práctica, coadyuvándole los señores socios como no puede menos de suceder, el lema del Instituto: ILUSTRACION Y BENEFICENCIA» ${ }^{29}$.

Así pues, junto a los cursos de música, declamación, canto y pintura (por citar sólo los de carácter filarmónico entre los muchos que organizaban las cátedras) impartidos a los socios, el Instituto sufragaba las enseñanzas primaria y artística de personas carentes de recursos.

Una de las aportaciones más destacadas de la institución a la vida musical madrileña fue el inicio de los llamados «ensayos líricos» en 1841. Con la novedosa iniciativa se pretendía dar la oportunidad a sus socios-alumnos de canto para que participasen en la interpretación de composiciones líricas, en funciones abiertas al público. Su importancia estriba, entre otras cosas, en que fueron un primer paso en el atribulado camino hacia el desarrollo de la ópera nacional en nuestro país - tan deseado por algunos-, todavía ausente en el repertorio habitual. Por otra parte, contribuyeron al sostenimiento económico de la sociedad a través del cobro de las entradas, hecho que derivó en conflictos con los empresarios teatrales al cabo de varios años, conflictos decisivos para el futuro declive de las sociedades musicales.

El perfeccionamiento de los «ensayos líricos» condujo a una obra de más envergadura, la «Escuela lírico-práctica» de la Sección de Música. Para abordar un proyecto tan ambicioso, el establecimiento contó con la ampliación de sus instalaciones, que, tras varios años de trabajos y de ubicación en un salón-teatro temporal, culminó en la inauguración de un teatro propio en 1845. La «Escuela lírico-práctica» tuvo derivaciones de innegable trascendencia en lo tocante a

29. «Instituto Español». El Entreacto, año I, n 77. Madrid (22-XII-1839), p. 305.

266

(c) Consejo Superior de Investigaciones Científicas Licencia Creative Commons 3.0 España (by-nc)
Anuario Musical, 58 (2003)

http://anuariomusical.revistas.csic.es 
la difusión de repertorio. No sólo por ser «un excelente «laboratorio» para poner en escena obras de los artistas vinculados a sus cátedras» ${ }^{30}$ - con la subsiguiente proyección de los compositores españoles-, sino porque, aparte de óperas, fue punto de lanzamiento del repertorio nacional decimonónico por excelencia, la zarzuela:

«Sabemos que en el Instituto Español se está ensayando una zarzuela con el título la Pastora del Manzanares, poesía de D. Basilio Sebastián Castellanos, música de los profesores de la sección D. José Soberano (padre), D. Mariano Soriano Fuertes, D. José Soberano (hijo) y D. Florencio Lahoz. Según nos han informado, ha sido casi improvisada la música por el corto tiempo que se ha dado para componerla, y por consiguiente sin pretensiones de ninguna especie» ${ }^{31}$.

La construcción de un teatro propio trajo consigo, aparte de muchos gastos, nuevas dificultades asociadas a la competencia con los demás coliseos madrileños. Ante la complejidad de sustentarlo con las representaciones de los socios (aficionados), se decide contratar una compañía profesional que alterne allí sus funciones con las de aquéllos. Éste será uno de los factores desencadenantes de la crisis que las sociedades artísticas atravesarán en la segunda mitad de los cuarenta. El teatro del Instituto pervivió hasta 1861, año en que fue demolido tras haber sido alquilado por varias compañías.

Las tres sociedades que hemos comentado constituyeron los centros socio-culturales más dinámicos de la capital durante el segundo tercio del siglo, completando su acción la desarrollada por otros establecimientos en la misma línea. El Museo Lírico, fundado en 1840, desplegó una intensa actividad artística y literaria a través de sus secciones y cátedras, donde impartieron lecciones reputados profesores que tomaron parte igualmente en otras sociedades:

«En el museo Lírico y Artístico, se aprobó en 26 de febrero último y 18 del actual, un proyecto sobre establecimiento de cinco cátedras bajo la dirección de los sugetos (sic) siguientes: D. Miguel Agustin Príncipe, de la de Literatura, de que es presidente: D. José García Luna de la de declamación de que es presidente: D. Indalecio Soriano Fuertes, de la de composición y armonia siendo socio facultativo de la sección de música. D. Joaquin Espin, presidente de la sección de música, de la cátedra de canto. D. Mariano Soriano Fuertes, socio facultativo de la seccion de música, está encargado en union con los demas maestros de la seccion, de la enseñanza de la clase de solfeo, que será diaria. Creemos que ofrece muchas ventajas este establecimiento á toda la juventud filarmónica, deseosa de instruirse en el arte do recibe el alma inspiraciones dulces y melodiosas» ${ }^{32}$.

Contó también con un teatro para sus sesiones filarmónicas y dramáticas, donde se representaban generalmente comedias breves, zarzuelas andaluzas y óperas. Por otro lado, y al igual que el Instituto, desarrolló su vocación benéfica mediante la creación de una caja de socorros mutuos para artistas y literatos.

30. Cortizo, $\mathrm{M}^{\mathrm{a}} \mathrm{E}$. «El asociacionismo en los orígenes de la zarzuela moderna»..., p. 54.

31. «Crónica nacional». La Iberia Musical, año I, n 3. Madrid (16-I-1842), p. 12.

32. «Crónica nacional». La Iberia Musical, año I, nº 13. Madrid (27-III-1842), p. 51. 
La animada vida del Museo se halla reflejada en las crónicas de la prensa especializada, que revelan una dinámica similar a la del Liceo en sus «sesiones de competencia» semanales, como muestra la siguiente nota del año 1842:

«Esta sociedad continúa en progresión ascendente, y con una concurrencia cada vez mas numerosa y brillante. En la sesion de competencia, verificada la noche del lunes 6, presentó la sección de literatura una animación estraordinaria (sic), habiendo leido los señores Príncipe, Satorres, Fr. Gerundio, Retes, Villergas y Abenamar, ó sea D. Santos Lopez Pelegrín el cual verificó su primera lectura en el Museo aquella noche. La seccion de música presentó por su parte un coro del Ivanhoe, y otro de la Bella aurora, cantados por todos los individuos de la seccion; un duo del Assedio de Calais, música de Donizzeti, por las señoritas Villar y Jardin; el aria de tenor de la Caritea, música de Mercadante, cantada por el señor Gonzalez; la melodía italiana del señor Espin, titulada Il palpito dil cor, por la señorita Villar; y últimamente, el aria de tiple de la Semiramide, por la señorita Jardin. Todos los individuos se hicieron acrehedores (sic) á los aplausos de la sociedad, y todos rivalizaron en deseos de dar el posible brillo á la funcion. Echóse sin embargo de menos la orquesta, y nosotros no podemos prescindir de dirigir á los individuos que la componen una interpelacion amistosa» ${ }^{33}$.

A partir de 1843 el establecimiento se disuelve «a consecuencia de las últimas contestaciones habidas entre su antiguo presidente y su última junta directiva. En consecuencia va a formarse otra nueva sociedad con los elementos de la que acaba de disolverse, la cual tomará el nombre de Museo Matritense ${ }^{34}$, que continuará el rumbo de la entidad original, aunque con no pocos tropiezos:

«En la noche del lunes 27 del finado marzo tuvo lugar la inauguracion del Museo Matriten$s e$. El magnífico salon de esta sociedad ha sufrido grandes alteraciones en sus adornos y colgaduras, presentando una perspectiva sorprendente á primera vista por el gusto y la elegancia de los dichos adornos. La concurrencia de esta noche fue numerosa y brillante, y la animación y alegria reinaban por todas partes.

Un himno á las artes á grande orquesta, composición del presidente de la seccion de música, Joaquin Espin y Guillen, dió principio á la funcion. Los señores socios y socias de esta seccion lo cantaron con todo el fuego y animación que tiene el hermoso coro lleno de robustez y brillo, y las estrofas cuya música está llena de ese sentimentalismo que el Sr. Espin sabe dar en sus composiciones tan buenas pinceladas fueron bien desempeñadas por las señoritas que las cantaron.

Siguió a este coro la comedia en cinco actos Un casamiento sin amor, en la cual la señorita Tablares desplegó sus grandes conocimientos dramáticos y la gracia y donaire con que la naturaleza la ha dotado. La señorita López y los señores Cernadas, Castejón y Verdes, no dejaron nada que desear á la numerosa reunion. Concluyendo toda la funcion con el coro de introducción de la Straniera á toda orquesta y cantado por los socios de la seccion de música.

La sociedad salió complacida y encomiando estraordinariamente el lujo y verdad de los trages y la bonita y sencilla decoración.

33. «Museo Lírico, Literario y Artístico». La Iberia Musical, año I, n² 24. Madrid (12-VI-1842), p. 95.

34. «Crónica nacional». El Anfión Matritense, año I, n 10. Madrid (12-III-1843), p. 80. 
Brillantes han sido siempre las sesiones que ha dado el Museo, numerosos partidarios ha tenido siempre; pero siempre ha tenido tambien una mala direccion y un padrastro que no deseaba sino minar los cimientos de esta sociedad y sepultarla en la nada. Tres inauguraciones ha tenido el Museo y esperamos que con la direccion acertada que hoy tiene no se efectuará la cuarta, pues si se efectuase seria la muerte cierta del Museo Matritense» ${ }^{35}$.

1840 registra asimismo la fundación de La Unión. Nacida con idéntica finalidad, aunque pretensiones más modestas, su éxito entre la sociedad distinguida no tarda en rebasar las previsiones iniciales, convirtiéndose en punto de encuentro de la pujante burguesía, ávida de entretenimientos y contactos sociales: «las máscaras de la sociedad de La Unión, están cada día más en boga; niñas esbeltas, bonitas y elegantes; galanes muy apuestos, acicalados, cumplidos y elegantes se disputan el obsequiar a las bellas madrileñas; fraternidad, buen humor, bonita música, abundante ambigú... Creemos que con tales elementos no puede faltar nunca amenidad y solaz en La Unión» ${ }^{36}$. Esta sucinta reseña retrata ingenuamente una situación que será ampliamente criticada en la prensa por parte de aquéllos que ven en las sociedades un espacio «adulterado», eminentemente destinado a la vida social, con sus galanteos, su hipocresía y sus convencionalismos, - de forma paralela a lo que sucedía en los salones privados-, en detrimento de su finalidad original, ahora relegada a segundo plano, y con sus lamentables derivaciones en lo concerniente a la calidad del repertorio y de las interpretaciones.

Otras entidades que amenizaron con sus programas la existencia de los burgueses madrileños fueron El Genio, La Academia Filarmónica Matritense - al poco fusionada con el Instituto Español-, la Venus, la Talía, El Numen, El Parnaso, el Centro Artístico y Literario, la Sociedad Patriótica del Fomento de la Ilustración «y otras varias de que no nos acordamos y de cuya administración no tenemos a la vista ningunos informes» ${ }^{37}$, como expone Francisco Montemar en las páginas de La Luneta. Todas ellas son de carácter específicamente burgués, no popular, y su florecimiento corre paralelo al de la clase media liberal y mercantil, cuya posición económica más holgada le permitía buscar otros cauces de entretenimiento y, al tiempo, de entablar relaciones sociales y hacer ostentación de su esplendor. Esta burguesía, señala Celsa Alonso, «no disponía en sus casas de salones lo suficientemente espaciosos y lujosos como para organizar reuniones sociales, conciertos y veladas artísticas. Por eso crearon, mediante suscripción, sociedades instructo-recreativas y artístico-musicales, como se las conocía entonces ${ }^{38}$. Según la autora, el funcionamiento de las sociedades españolas de estas características acusa la herencia de un modelo asociativo dieciochesco, típicamente inglés y urbano, propio de las llamadas «Assembly Rooms», creadas para el solaz de las clases pudientes, donde música y literatura asumieron un papel esencial.

35. «Crónica nacional». La Iberia Musical y Literaria, año II, $\mathrm{n}^{\circ}$ 14. Madrid (2-IV-1843), p. 112.

36. «Crónica nacional». La Iberia Musical y Literaria, año II, $n^{\circ} 7$. Madrid (12-II-1843), p. 55.

37. Montemar, Francisco. «Entreacto. Las sociedades. Primera parte. Las sociedades por dentro» y «Entreacto. Las sociedades. Segunda parte. Las sociedades por fuera». La Luneta, $\mathrm{n}^{\circ} 14$. Madrid (14-I-1847), p. 55.

38. Alonso, C. «Un espacio de sociabilidad...», p. 24. 
La impronta de una práctica inglesa anterior no disminuye las similitudes con otra temporalmente más próxima — abordada por Jean Quéniart en sus estudios sobre sociabilidad decimonónica-, procedente del mundo francés, concretamente de los círculos pequeño-burgueses que organizaban sesiones musicales por suscripción en la mayoría de las ciudades durante los años treinta y cuarenta ${ }^{39}$. Maurice Agulhon, investigador también del fenómeno societario galo, ha subrayado su naturaleza propiamente burguesa, a diferencia de la aristocrática — propia de prácticas difundidas en el Antiguo Régimen-, por un lado, y de la popular, por otro. Respecto a la última no cabe duda. A su modo de ver,

«Il est évident a priori que la vie de cercle suppose de l'aisance (il faut quelque argent pour louer un local, payer la chandelle et le chauffage, l'abonnement aux journaux, l'enjeu des parties de cartes, la boisson) e du loisir (n'avoir pas de profession, ce qui est le cas du retraité ou du propriétaire rentier, ou avoir un bureau que ferme vers cinq heures, comme l'employés ou le négociant). La sociabilité des gens du peuple, qui ont moins de temps et d'argent, et que d'autre part, au moins á l'origine, ne savent pas lire le journal, a nécessairement des formes différentes ${ }^{40}$.

Al mismo tiempo se da un notorio contraste con la sociabilidad aristócrata de antaño, donde un particular recibía con frecuencia en su salón, a sus expensas, a un grupo de habituales:

«Un tel système implique en effet l'existence d'une vraie richesse chez le maître de maison, et d'une subordination morale (par la dépendance qu'entraîne le manque de réciprocité) chez ses hôtes. Par contraste, le cercle á l'anglaise, où il n'y a que des associés, est une institution égalitaire, et que, de plus, Peut théoriquement être établie par des gens de quelque aisance certes, mais pas nécessairement riches; elle est donc —-pour l'époque-deux fois révolutionnaire, ou si l'on préfère, deux fois bourgeoise ${ }^{41}$.

Sintetizando de alguna manera las ideas que hemos ido presentando en la exposición de las sociedades comentadas (Ateneo, Liceo, Instituto, Museo, etc.), podríamos decir que las sociedades musicales españolas, incluidas en el epígrafe de las instructo-recreativas, fueron corporaciones surgidas en el seno de la burguesía durante la primera mitad del XIX, retomando una idea preexistente que la coyuntura político-económica anterior no había permitido llevar a la práctica.

39. QUÉNIART, Jean. «Les formes de la sociabilité musicale en France et en Allemagne (1750-1850)», en Sociabilité et societé bourgeoise en France, Allemagne et en Suisse (1750-1850). Paris, Recherche sur les Civilisations, 1986, pp. $135-146$.

40. «es evidente a priori que la vida de círculo implica desahogo económico (hace falta dinero para alquilar un local, pagar el alumbrado y el calentamiento, la suscripción a los periódicos, la organización de partidas de cartas, la bebida) y de tiempo libre (no tener profesión, lo cual es el caso del jubilado o del rentista, o estar en una oficina que cierra hacia las cinco de la tarde, como el empleado o el negociante). La sociabilidad de la gente del pueblo, con menos tiempo y dinero, y que, por otra parte, al menos en su origen, no sabe leer el periódico, presenta, necesariamente, formas diferentes». AGULHON, Maurice. Le cercle dans la France bourgeoise 1810-1848.Etude d'une mutation de sociabilité. Paris, Librerie Armand ColinCentre de Recherches Historiques, 1977, p. 18.

41. «Tal sistema implicaba auténtica riqueza por parte del anfitrión, así como subordinación moral (por la dependencia que implica la falta de reciprocidad) por parte de sus invitados. Por el contrario, el círculo a la inglesa - modelo adoptado en Francia y, algo más tarde, en España-, donde sólo hay socios, es una institución caracterizada por la igualdad, y que, además, puede ser establecida por personas de cierto nivel económico, en teoría, pero no necesariamente ricas; es, por tanto —para la época-, dos veces revolucionaria, o, si se prefiere, dos veces burguesa». Ibidem, p. 29. 
En este punto es importante comentar un hecho sin duda innovador, sin precedentes en el terreno de la sociabilidad institucionalizada: la admisión de miembros femeninos. A diferencia de lo que sucedía en las Económicas y en el Ateneo - donde las damas dispusieron de una sección aparte o fueron admitidas tras muchos años de funcionamiento-, en las sociedades instructo-recreativas varones y mujeres solían participar conjuntamente en las actividades, en pie de igualdad. Ello es, sin duda, un avance en la evolución de la mentalidad contemporánea y ha sido estimado por algunos como signo de modernidad.

Sufragadas por la contribución de sus socios - con lo que se pagaban el alquiler de los locales y el profesorado-, se organizaban en secciones cuyas actividades iban encaminadas a la instrucción en diversas disciplinas (cátedras), enriquecida con exposiciones, conciertos, representaciones líricas y dramáticas, juegos florales, concursos, tómbolas, etc. que amenizaban las jornadas de los aficionados, sobre todo en las concurridas «sesiones de competencia», de gran éxito a mediados de siglo. Allí los participantes demostraban las habilidades desarrolladas en las distintas secciones y, aparte de ser escenario de eclecticismo artístico, con la riqueza que eso significa, su atractivo social los convirtió en espacios de obligada concurrencia para burgueses y aristócratas. Además, algunos centros disponían de biblioteca, gabinete de lectura y sala de juegos en sus instalaciones, con el aliciente que eso supone para la captación de los desocupados.

A las aportaciones de los socios hay que añadir las de compositores e intérpretes profesionales, que en ocasiones colaboraban en conciertos y representaciones, aparte de la labor desempeñada en las cátedras.

Algunas entidades compaginaron la faceta artístico-instructiva con la benéfica, por medio de la instrucción a grupos de personas con pocos recursos o la organización de conciertos a beneficio de artistas en precaria situación económica, caso frecuente tras la desamortización.

El repertorio musical abordado en las sociedades continúa en la línea de lo visto para los primeros años treinta, manteniéndose así hasta mediados de los cuarenta. La música vocal está copada por fragmentos de ópera italiana, arreglados para piano cuando no se disponía de orquesta. Arias, dúos, coros y oberturas de Rossini seguían estando a la orden del día, pero su protagonismo en las preferencias del público comienza a ceder en favor de la música de Bellini y Donizetti:

«El jueves último se ha ejecutado en el Liceo una bonita función lírica dirigida por el maestro Basilio Basily, con el celo y acierto que distingue á este artista. He aquí el programa:

Sinfonia nueva á grande orquesta de la ópera de D. Pasquale, del maestro Donizetti.

Coro de la Figlia del Reggimento.

Variaciones de piano del maestro Herz, por don José de Londoño.

Cavatina con coros de la ópera Beatrice di Tenda, por la señorita doña Manuela Catalan y las señoras de la quinta seccion.

Cavatina con coros del Elixir, del maestro Donizetti, cantada por el Sr. D. Francisco Salas con decoraciones y trages (sic).

Duo del Elixir, de tenor y bajo, por los señores D. Carlos Sentiel y D. Francisco Salas, con decoraciones y trages. 
Acto tercero de Lucrezia Borgia, por la señora doña Manuela Oreiro de Vega y los señores Salas y Sentiel, con decoracion y trages $[\ldots] »^{42}$.

Eso sucedía en las veladas de variado repertorio. En otras ocasiones se llegaron a montar óperas enteras, con escenografía y vestuario, cuando la infraestructura y el presupuesto lo permitían. Por otra parte, las sociedades artístico-culturales sirvieron de escenario para el primer contacto del público con la zarzuela moderna. Así sucedió, según acabamos de ver, en el Instituto Español, donde se estrenaron títulos como ¡Es la chachi!, ¡La sal de Jesús!, Palo de ciego, Colegialas y soldados, Misterios de bastidores, Las almas del purgatorio y muchas otras de Mariano Soriano Fuertes, Rafael Azcona, Cristóbal Oudrid, Rafael Hernando y Fernando Gardín.

Junto al auge del italianismo se percibe un alza de la canción española y andaluza. A menudo las piezas de corte populista eran interpretadas con decoración y vestuario adecuados al tema, de modo similar a lo que se estilaba con las arias operísticas y, en ocasiones, intermediaban la representación de comedias. Celsa Alonso, tras ahondar en el tema, asocia la pujanza de un género típicamente hispano con las nuevas inclinaciones de tinte nacionalista vinculadas a la propagación del movimiento romántico, que, ahora más que nunca, impele a valorar lo propio, restaurando tendencias y actitudes en boga durante el siglo anterior - como el gusto aristocrático por el plebeyismo, el casticismo-, recientemente desplazadas por las modas extranjeras. «La canción española sufrió bastante impulso, debido tanto al éxito del costumbrismo y el pintoresquismo, como a la continuidad del plebeyismo de raíz dieciochesca en la actitud de las clases elevadas, protagonizando una etapa de esplendor, que coincide con el desarrollo del romanticismo literario en poesía y drama, el costumbrismo de escenas y de tipos, las novelas por entregas, la expansión de las publicaciones periódicas (en particular el inicio de la prensa musical) y el inicio del nacionalismo romántico». En definitiva, «el populismo de la canción española se acomoda perfectamente al pintoresquismo de la cultura francesa que comenzaba a ponerse de moda en las soirées» ${ }^{43}$.

El hecho de mezclar arias italianas con canciones de estilo popular en los repertorios de salones, ya fuesen particulares o de instituciones, puede parecer de lo más extraño o, cuando menos, curioso, por la disparidad de sus caracteres. Sin embargo, era moneda corriente entre los aficionados. R. Mitjana, en una invectiva contra tal práctica, llegó a calificar de «sacrilegios estéticos» esas combinaciones, juzgando que «el gusto por las melodías de tan diferente estilo se explica sin demasiada dificultad: por una parte se obedecía a las imposiciones de la moda y, por otra, se satisfacía el instinto de la raza» ${ }^{44}$. Tras ejemplificar tal «extravagancia» con un dúo formado por una cavatina y un polo gitano publicados por un diario artístico de la época, el autor estima que «el efecto no puede ser más grotesco y ridículo, y nos muestra hasta qué punto había

42. «Crónica nacional». La Iberia Musical y Literaria, año II, $\mathrm{n}^{\circ} 18$. Madrid (30-IV-1843), p. 143. $186-189$.

43. Alonso, Celsa. «Los salones: un espacio musical para la España del XIX». Anuario Musical, n 48, 1993, pp.

44. Mitjana, Rafael. La música en España (Arte religioso y arte profano). París, 1920. Edición consultada: Historia de la Música. Madrid, Ministerio de cultura, 1993, p. 430. 
llegado la aberración del gusto. Lo peor es que esto se cantaba en los medios cultos y que el ejemplo dista mucho de ser único. No podemos disculpar a los músicos españoles de tales sacrilegios estéticos. En general los autores de estas monstruosidades eran famélicos italianos vinculados a las compañías de ópera deseosos de ganar algunos céntimos halagando los bajos instintos del público» ${ }^{45}$. Actualmente, habituados como estamos a la diversidad, quizá no encontremos tan incomprensible esa complacencia en dos estéticas diferentes, sino, al contrario, muy enriquecedora.

El repertorio instrumental sostiene relación evidente con el vocal en tanto que el grueso de la producción lo integran piezas para piano sobre temas operísticos (fantasías, variaciones) de autores mayormente extranjeros, léase Herz o Thalberg -españoles en alguna ocasión, como Masarnau o Pedro Albéniz, y a veces socios aficionados-, completado con piezas variadas para sólo (violín, flauta, arpa) o pequeño conjunto instrumental, generalmente dúos (piano y arpa/guitarra/violín) y tríos. También eran frecuentes las danzas para piano, sobre todo valses y rigodones, así como los popurrís sobre aires nacionales, muchos de ellos escritos por compositores aficionados.

La prensa musical de los primeros años cuarenta recoge ya críticas a la calidad de este repertorio, consecuencia del diletantismo de sus intérpretes más habituales:

«El 26 de febrero celebró el Instituto Español una sesion de competencia á la que asistimos. La seccion de música no nos presentó novedad alguna notable y aun se suprimieron algunas de las piezas que anunciaba el programa; nada mas natural en una seccion compuesta de aficionados en su mayor número, nada mas conveniente á la misma seccion que en vez de llenar el programa con un número escesivo ( $\mathrm{sic}$ ) de piezas, se egecuten ( $\mathrm{sic}$ ) pocas, buenas y elegidas, aunque no se anuncien. El Instituto Español tiene bastantes pruebas de nuestro aprecio, mas nuestro primer deber es el lustre y buen nombre del arte músico, y remediar en lo posible los abusos que encontremos indicándolos con la imparcialidad que nos es familiar» ${ }^{46}$.

La mediocridad de intérpretes y creadores, tanto en obras musicales como en literarias, es uno de los factores que intervienen en la crisis de las sociedades a mediados de siglo, al no poder competir con el nivel demostrado por los artistas profesionales que trabajaban en los teatros de la ciudad, pues, como expresaba M. Soriano Fuertes en las páginas de La Iberia Musical y Literaria, «no es la ejecución de un principiante la misma que la de un artista consumado, y esto el público lo había de notar» ${ }^{47}$. El crítico denunció sin contemplaciones el rumbo equivocado que habían emprendido las sociedades al abandonar su inicial finalidad artística en favor de la meramente especulativa, debido a la nefasta gestión de sus directivos. En el plano operístico, las prometedoras iniciativas pedagógicas (como la escuela lírico-dramática del Instituto Español) no habían fructificado en artistas de calidad, sino todo lo contrario, perjudicando a los auténticos

45. Ibidem nota anterior.

46. «Crónica nacional». La Iberia Musical, año I, n 10. Madrid (6-III-1842), p. 40.

47. «Instituto Español». La Iberia Musical y Literaria, año II, n² 2. Madrid (8-I-1843), p. 12. 
profesionales de los teatros municipales, que, aunque de mayor nivel, no veían llenar su aforo a causa de las malas representaciones ofrecidas por socios aficionados ${ }^{48}$. El caso se agrava si pensamos en el peso que había adquirido el repertorio dramático en detrimento de otras alternativas, como la música de cámara. Las veladas literario-musicales perdieron, asimismo, la resonancia de los años previos, lo cual empobreció aún más el espectro ofertado en las sociedades.

La siguiente reseña periodística sobre el Instituto Español de 1845 es ya muestra de una situación poco halagüeña:

«De intento no hemos hablado en nuestros números anteriores de la sociedad del Instituto Español, y varias eran las razones que nos impulsaron á guardar este silencio. Cuando ibamos á tributar nuestros elogios por la funcion dispuesta para la tarde del 24 de diciembre: cuando ibamos á calificar de poco acertada la pública que siguió dos dias después, cuando esperábamos con ansia los exámenes de los alumnos y alumnas cuya educación sostiene esta sociedad, y de que particularmente tenemos las mejores noticias, hé aquí que se manifiesta hallarse precisada la sociedad á desalojar el local que ocupaba, y creimos que serían fuera de toda sazon nuestras observaciones. En una época en que las sociedades artísticas y literarias, dejenerando (sic) de su primitivo objeto, se han convertido en comedias caseras por mas ilusiones que en contrario queramos hacernos, sensible nos pareció que el Instituto (cuyas clases y asignaturas se ven tan frecuentadas por multitud de individuos pertenecientes desde la clase media hasta la mendicidad) dejase de existir, y en verdad que probabilidad ninguna encontrábamos de que pudiese continuar, pues la falta de locales apropósito y otras mil causas hacian imposible que sus socios volvieran á reunirse» ${ }^{49}$.

La concurrencia disminuye y, los que siguen asistiendo, lo hacen sin interés hacia lo que allí se les ofrece, acudiendo sólo por el aspecto meramente social. De no haber muerto en 1837 , las aceradas críticas dirigidas por Larra a los convencionalismos y apariencias imperantes en los salones «de buen tono» habrían sido nuevamente aplicadas por Fígaro a las veladas que la élite madrileña frecuentaba diez años más tarde. La representación en el escenario es ignorada, desplazada en favor de la representación en palcos y lunetas, donde los espectadores de antes se convierten en intérpretes de ahora, protagonistas de la comedia social:

«Cuando principiaron á fomentarse estos teatros de aficionados, como todo lo nuevo, llamaron la atención; la gente acudia con afán, tomaba parte en la satisfacción de los que representaban y aun los aplaudia con prodigalidad. Pero, hoy en dia, con tantas sociedades, se ha estragado el gusto y la gente se reune por charlar, coquetear y murmurar siendo muy pocos los que desean ver la funcion [...]. Se da principio á la representación y separando una docena de personas que se colocan en las primeras filas con el deseo de ver la comedia, las demas entablan una conversación animada [...].Es preciso concluir en que pasó el entusiasmo por las sociedades, y para que estas volvieran á sus primitivos tiempos, era conveniente cerrarlas por algunos años y que experimentasen los amantes la diferencia de andar á salto de mata sin poder hablar á sus Dulcineas, encontrar-

I-1844).

48. «Estado de nuestras sociedades artísticas de Madrid». La Iberia Musical y Literaria, año III, nº 7 . Madrid (25-

49. El Artista Español (periódico de todo, menos de religión y política). N 14, Madrid (31-I-1845), p. 3.

Anuario Musical, 58 (2003)

(c) Consejo Superior de Investigaciones Científicas Licencia Creative Commons 3.0 España (by-nc) 
las seguramente tres o cuatro dias á la semana en estas reuniones, pudiendo desahogar en miniatura su pasion.» ${ }^{50}$

Las sociedades artísticas, en palabras de R. Mitjana, «habrían podido ser de gran utilidad para el desarrollo del arte y la educación del gusto. Desgraciadamente casi siempre carecieron de bases sólidas y cayeron en los mismos errores; en lugar de hacer música seriamente se prefirió halagar la vanidad de los aficionados ${ }^{51}$.

Dejando a un lado las valoraciones, y como contrapunto a lo dicho, se ha de reconocer el papel de primer orden desempeñado por las sociedades artístico-culturales en la difusión de un repertorio musical hasta entonces vedado a la clase burguesa: la música operística y, en menor medida, la de cámara. Se trata de un nuevo público, nuevos consumidores de un género que en el XVIII había hecho las delicias de los restringidos círculos aristocráticos.

En 1849 el Gobierno asesta un duro golpe a las sociedades artísticas que, como el Instituto Español, disponían de su propio coliseo. La nueva legislación aportada por el Reglamento de Teatros impone unas condiciones para el funcionamiento de los teatros del reino que difícilmente podrán ser cumplidas por aquellas instituciones. El Decreto Orgánico de febrero establece un control del repertorio, dividiendo los teatros por géneros, de modo que en cada coliseo sólo podrá haber funciones de un tipo - el teatro de la Comedia, por ejemplo, como ahora se llamará el de Instituto, será dedicado exclusivamente a teatro de verso-. Por otro lado, el malestar de los empresarios teatrales ante la competencia de algunas sociedades que ofrecen representaciones dramáticas en sus propios teatros compele a las autoridades a establecer el pago de una licencia a tal efecto. Si bien ciertas instituciones lograron sortearlos durante un tiempo o, al menos, obtener reducciones, las trabas económicas obstaculizaron de forma insalvable la actividad de los aficionados, al no poder afrontar los nuevos impuestos, con el subsiguiente languidecimiento de su actividad en los años cincuenta.

A decir verdad, durante la primera década del reinado isabelino se lleva a cabo una política cultural claramente a favor de los teatros públicos, plasmada en la restauración de los existentes y la construcción de nuevos coliseos, que coloca a España entre las primeras potencias europeas en lo referente a infraestructura teatral. Ello supone una intensa rivalidad con los espacios de las sociedades, a la que se añade la ejercida por teatros de carácter privado en hoteles y residencias.

A los factores de índole artística y económica comentados habría que sumar las medidas represivas adoptadas durante esos mismos años por el Gobierno isabelino - políticamente definidos como la Década Moderada-, quien, receloso de todo tipo de asociación (como posible foco de insurrección política), endurece la legislación en materia de corporativismo. La restricción de la libertad política a la que hemos aludido en otro apartado del presente trabajo, con sus implicaciones sociales, se manifiesta de un modo especial entre 1844 y 1854 , afectando ineluctablemente a las sociedades artísticas.

50. Montemar, F. «Entreacto. Las sociedades. Segunda parte. Las sociedades por fuera»..., p. 55.

51. Mitjana, R. Historia de la música en España..., p. 448. 
No es de extrañar, pues, que tan desafortunado cúmulo de adversidades impulsase a Mesonero Romanos, precisamente al final de la Década, cuando «El Curioso Parlante» reedita su Manual de Madrid -ya obsoleto en ciertos aspectos de la capital, entre ellos los establecimientos socio-culturales-, a introducir desalentadoras rectificaciones con relación a los «gloriosos» y prometedores años pasados, lamentándose del curso seguido por creadores e instituciones:

«Pero aquel espectáculo duró muy poco: hoy, pasados aquellos días de ardiente fe y de sed entusiasta de gloria, la tendencia del siglo inclina a materializar los goces, a utilizar interesadamente las inteligencias. Por eso los Liceos, las Academias en que éstas se ostentaban espontánea y generosamente, y por solo el deseo de fama, desaparecieron ya; por eso los desamparados autores corrieron a las redacciones de los periódicos, a la tribuna, a la plaza pública, a conquistar no aquellos laureles que en otro tiempo bastaban a su ambición, sino los atributos del poder o los dones de la fortuna» ${ }^{52}$.

No obstante, tras la crisis de los años cuarenta y cincuenta, se aprecia un resurgimiento de las sociedades culturales y recreativas de naturaleza burguesa durante el último tercio del siglo, materializado en la fundación de entidades de nuevo cuño o en la transformación de otras preexistentes, fenómeno que ha de enmarcase en el florecimiento del asociacionismo en términos generales — sin precedentes en el ámbito obrero, de carácter político, sindical, lúdico o instructivo- de estos años. A partir de los sesenta asistimos a un renacimiento de liceos y ateneos por todo el país, restaurando la actividad desarrollada por sus antecesores del período romántico: veladas literario-musicales, bailes, representación de óperas y zarzuelas, secciones especializadas en distintas enseñanzas, certámenes, exposiciones, etc. Ejemplo de ello fue El Fomento de las Artes, surgida bajo otra denominación a finales de los cuarenta, y dirigida originalmente a la formación y defensa de los intereses de los obreros, pero que los avatares políticos de años posteriores transformaron en sociedad eminentemente burguesa, nutrida a base de efectivos de la clase media en las últimas décadas del siglo.

También los casinos, a pesar de ser centros eminentemente recreativos, introducen el elemento filarmónico como complemento de su oferta disipativa, junto a charlas, juegos y lectura de periódicos. Por otra parte, es importante señalar la aparición de numerosas entidades que, inicialmente vinculadas a determinados sectores mercantiles y con carácter exclusivamente profesional, derivaron finalmente en sociedades lúdicas. Tal es el caso de los Círculos Mercantiles, en los que las veladas musicales hacían las delicias de la concurrencia.

Finalmente, no hemos de olvidar la aportación específicamente filarmónica hecha por determinadas instituciones durante el último tercio del siglo. Nos referimos a escuelas de música y conservatorios, quienes cedían sus propias salas (habitualmente destinadas a los alumnos, los cuales hacían exhibición anual de sus progresos en lo que por entonces se denominaban ejercicios) a otras instituciones para la realización de conciertos, en ocasiones con carácter benéfico, tal y como nos muestra el siguiente testimonio de 1867 :

52. Mesonero Romanos, R. Nuevo Manual histórico-topográfico-estadístico y descripción de Madrid. Madrid, Viuda de D. Antonio Yenes, 1854. Edición consultada: Obras Completas, Madrid, Atlas, 1967.

276

(c) Consejo Superior de Investigaciones Científicas Licencia Creative Commons 3.0 España (by-nc)
Anuario Musical, 58 (2003) http://anuariomusical.revistas.csic.es 
«El concierto que se verificó el viernes $1^{\circ}$ de Febrero, á las nueve de la noche, en el gran salon del Conservatorio, organizado por el distinguido pianista señor Pujol, á beneficio de la Sociedad artístico-musical de Socorros mútuos, fue una solemnidad musical, que dejará recuerdo en el ánimo de las personas que acudieron á oirle. Tomaron parte los Sres. Pujol, Monasterio, Amigó, Parera, Inzenga y la señorita Trillo. El Sr. Monasterio se mostró á la altura colosal que todos reconocemos, lo mismo que el Sr. Pujol y el Sr. Amigó, cuyos talentos de ejecutantes llamaron extraordinariamente la atención del público, que los aclamó con entusiastas aplausos. La señorita Trillo, lo mismo que el Sr. Parera, desempeñaron de una manera satisfactoria las piezas de canto que les estaban encomendadas, así como el señor Inzenga, que estuvo muy feliz en una lindisima galop á cuatro manos, ejecutada con el Sr. Pujol $[\ldots] \gg^{53}$.

Del mismo modo se constata la cesión de espacios a tal efecto por parte de empresas editoriales, en cuyos salones —el de Benito Zozaya, el de Eslava, Romero- ostentaron sus dotes interpretativas encumbrados artistas de la época. 